\title{
Drought and Elevated Carbon Dioxide Impact the Morphophysiological Profile of Basil (Ocimum basilicum L.)
}

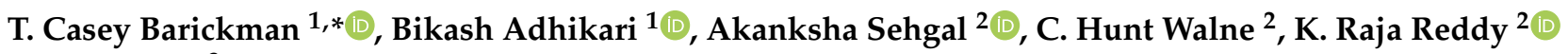 \\ and Wei Gao ${ }^{3}$ \\ 1 North Mississippi Research and Extension Center, Mississippi State University, Verona, MS 38879, USA; \\ ba917@msstate.edu \\ 2 Department of Plant and Soil Sciences, Mississippi State University, Mississippi State, MS 39762, USA; \\ as5002@msstate.edu (A.S.); chw148@msstate.edu (C.H.W.); krreddy@pss.msstate.edu (K.R.R.) \\ 3 USDA UVB Monitoring and Research Program, Natural Resource Ecology Laboratory, \\ Department of Ecosystem Science and Sustainability, Colorado State University, Fort Collins, CO 80523, USA ; \\ wei.gao@colostate.edu \\ * Correspondence: t.c.barickman@msstate.edu; Tel.: +1-(662)-566-2201
}

\section{check for} updates

Citation: Barickman, T.C.; Adhikari, B.; Sehgal, A.; Walne, C.H.; Reddy, K.R.; Gao, W. Drought and Elevated Carbon Dioxide Impact the Morphophysiological Profile of Basil (Ocimum basilicum L.). Crops 2021, 1, 118-128. https://doi.org/10.3390/ crops1030012

Academic Editors: Fulai Liu, Mohammad Anwar Hossain and Mohammad Golam Mostofa

Received: 22 September 2021 Accepted: 26 October 2021 Published: 31 October 2021

Publisher's Note: MDPI stays neutral with regard to jurisdictional claims in published maps and institutional affiliations.

Copyright: (c) 2021 by the authors Licensee MDPI, Basel, Switzerland. This article is an open access article distributed under the terms and conditions of the Creative Commons Attribution (CC BY) license (https:/ / creativecommons.org/licenses/by/ $4.0 /)$.

\begin{abstract}
Treating plants with elevated carbon dioxide $\left(\mathrm{eCO}_{2}\right)$ can increase their drought tolerance. Increased atmospheric $\mathrm{CO}_{2}$, a fundamental factor in climate change, may compensate for the droughtinduced reduction in crop growth and yield. Basil, being moderately sensitive to drought stress (DS), experiences several morphological changes under DS. Thus, we designed an experiment that addresses how DS and different levels of $\mathrm{CO}_{2}$ affect the overall morphological growth patterns during basil's early and late-season growth. The experiment was conducted under four different growth conditions: two water treatments, (1) a full-strength Hoagland's solution was added to the basil plants at $120 \%$ of the evapotranspiration each day, and (2) 50\% of the full-strength Hoagland's solution was added to basil plants for the drought treatment, alongside two levels of $\mathrm{CO}_{2}$ application [ambient 420 ppm $\left(\mathrm{aCO}_{2}\right)$ and elevated $\left.\left.720 \mathrm{ppm}\left(\mathrm{eCO}_{2}\right)\right]\right)$. The DS had a severe impact on the morphological traits of the shoot and root systems. Compared to control, DS reduced the marketable fresh mass (FM) by $31.6 \%$ and $55.2 \%$ in the early and late stages of growth. FM was highest under control $+\mathrm{eCO}_{2}$ (94.4-613.7 g) and lowest under DS $+\mathrm{aCO}_{2}(67.9-275.5 \mathrm{~g})$. Plant height under $\mathrm{DS}+\mathrm{aCO}_{2}$ and $\mathrm{DS}+\mathrm{eCO}_{2}$ reduced by $16.8 \%$ and $10.6 \%$ during the late season. On the other hand, dry mass percent (DM\%) increased by $31.6 \%$ and $55.2 \%$ under DS $+\mathrm{eCO}_{2}$ compared to control in the early and late stages of growth, respectively. This study suggested that $\mathrm{eCO}_{2}$ during DS significantly impacts basil morphological traits compared to $\mathrm{aCO}_{2}$. Besides, anthocyanin decreased by $10 \%$ in $\mathrm{DS}+\mathrm{aCO}_{2}$ and increased by $12.6 \%$ in DS $+\mathrm{aCO}_{2}$ compared to control. Similarly, nitrogen balance index, a ratio of chlorophyll and flavonoids, was recorded to be the highest in $\mathrm{DS}+\mathrm{aCO}_{2}$ (40.8) compared to any other treatments. Overall, this study indicates that the suppression of basil's morphophysiological traits by DS is more prominent in its later growth stage than in the earlier stages, and $\mathrm{eCO}_{2}$ played an important role in alleviating the negative effect of DS by increasing the DM\% by $55 \%$.
\end{abstract}

Keywords: climate change; physiology; ambient carbon dioxide; root image analysis; chlorophyll; flavonoids; nitrogen balance index

\section{Introduction}

The progression of climate change has made the global agricultural system vulnerable and has negatively impacted overall agrarian production [1]. The increasing linear warming trend of $0.74{ }^{\circ} \mathrm{C}$ over 100 years (1906-2005) and an expected increment of 1.1 to $6.4^{\circ} \mathrm{C}$ by the end of the 21st century have become a massive threat to agriculture [2,3]. Likewise, the increased atmospheric carbon dioxide $\left(\mathrm{CO}_{2}\right)$ is a fundamental factor in climate change and may compensate for the environmentally induced reduction in crop growth and yield [4]. The increasing level of global atmospheric $\mathrm{CO}_{2}$ (increased by $40 \%$ in 2011, i.e., 
278-390.5 ppm, and $413.35 \mathrm{ppm}$ in 2020) and its projected rise to $970 \mathrm{ppm}$ by the 21st century suggests a disturbance in climatic resilience to these stress factors [3]. The difference in rainfall patterns comprises a decline in rainwater and increased rainfall intensity over a short period [5]. Thus, it is unequivocal that higher temperatures and uncertain rainfall patterns will increase drying conditions worldwide [1]. Moreover, the anticipated growing drought due to elevated atmospheric $\mathrm{CO}_{2}$ and temperature will affect crops' growth and development, including basil (Ocimum basilicum L.) [6]. Therefore, it is crucial to assess climate change's influence on drought stress (DS) conditions for effective DS mitigation and crop adaptation $[7,8]$.

Basil is a culinary and medicinal herb that grows best under warm climatic conditions [9], with an optimal temperature range of $25-30^{\circ} \mathrm{C}$ [10]. However, a supplemental water supply is mandatory for the successful commercial production of basil. Several studies on the irrigation of basil have reported sensitivity to DS [11,12]. In general, basil $\left(C_{3}\right.$ plants) is grown under a wide range of environmental conditions. The plant reacts to DS via a series of morphological and cellular responses [13]. Previous research has indicated that DS decreases the number and branching of the stems, decreases internode length size, and reduces plant height (Ht), leaf area (LA), nodal length, stem diameter, root, and shoot yield in basil [14,15].

Basil's response to elevated $\mathrm{CO}_{2}\left(\mathrm{eCO}_{2}\right)$ has not been appropriately explored in the past. However, $\mathrm{eCO}_{2}$ is considered an innovative approach to improve plants' vegetative growth and nutritional value [16]. For example, $\mathrm{eCO}_{2}$ increased the yield of leafy vegetables by $38 \%$ and stem vegetables by $17 \%$ [17]. $\mathrm{eCO}_{2}$ also improves the biomass production in basil by $48 \%$ (Al Jaouni et al., 2018) and enhances chlorophyll content in the leaves [18]. A study on several leafy and stem vegetables reported that $\mathrm{eCO}_{2}$ enhanced the total biomass, yield, and dry matter content [17]. These morphological and nutritional benefits in basil due to $\mathrm{eCO}_{2}$ could help to increase its production efficiencies and nutritional value.

Many multidisciplinary approaches have reported the role and effect of DS and $\mathrm{eCO}_{2}$ levels on crops under global climate change scenarios in recent years. However, very few studies have investigated the interactive effects of $\mathrm{DS}$ and $\mathrm{eCO}_{2}$ on growth and basil development. Our understanding of the underlying implication of $\mathrm{eCO}_{2}$ under DS conditions in basil is still inconclusive. A previous study reported that basil production increased up to $80 \%$, increasing $\mathrm{CO}_{2}$ levels from 360 to $620 \mathrm{ppm}$ [4]. Similarly, the potential of DS tolerance in basil makes it an excellent alternative crop in dry regions $[15,19]$ due to its high economic value. Besides, the study of basil's morphophysiological parameters under DS will help identify basil traits resistant to DS [20]. Thus, the current study's primary purpose is to understand the effect of DS coupled with $\mathrm{eCO}_{2}$ on morpho-physiological attributes in basil.

\section{Materials and Methods}

\subsection{Plant Materials and Growing Condition}

Basil' Genovese (Johnny's Selected Seeds, Winslow, ME) seeds were sown in polyvinylchloride pots ( $15.2 \mathrm{~cm}$ diameter by $30.5 \mathrm{~cm}$ height) filled with a soil medium consisting of $3: 1$ sand/soil classified as a sandy loam ( $87 \%$ sand, $2 \%$ clay, and $11 \%$ silt) with a $500 \mathrm{~g}$ of gravel at the bottom of each pot. Six seeds were sown in each pot, and the plants were thinned to one plant per pot approximately seven days after emergence. Pots were organized in a randomized complete block design within a three-by-two factorial arrangement with temperature and $\mathrm{CO}_{2}$ treatments. A total of four Soil-Plant-AtmosphereResearch (SPAR) chambers represents two blocks (ten replications each). Each SPAR chamber consisted of 3 rows of pots (ten pots per row). All environmental growing conditions were kept the same throughout the experiment except for irrigation volumes and $\mathrm{CO}_{2}$. More detailed information on the SPAR chamber was earlier described by Reddy et al. [21] and Wijewardana et al. [22].

Basil plants were irrigated three times per day using an automated computer-controlled drip system with full-strength Hoagland's nutrient solution [23]. Irrigation was provided 
at 700,1200 , and $1700 \mathrm{~h}$, based on evapotranspiration values. Evapotranspiration rates expressed on the ground area $\left(\mathrm{L} \cdot \mathrm{d}^{-1}\right)$ throughout the treatment period were measured in each SPAR unit as the rate at which the cooling coils removed the condensate at 900-s intervals $[21,24,25]$. They were obtained by measuring the mass of water in collection devices connected to a calibrated pressure transducer.

\subsection{Treatments Application}

Basil plants were randomly assigned to each chamber consisting of 30/22 (day/night), in combination with ambient $(420 \mathrm{ppm})\left(\mathrm{aCO}_{2}\right)$ or elevated $(720 \mathrm{ppm})\left(\mathrm{eCO}_{2}\right)$ carbon dioxide concentrations. The daytime temperatures were initiated at sunrise and nighttime temperatures $1 \mathrm{~h}$ after sunset. There were two water treatments, imposed at 14 days after sowing (DAS) for the experiments: (1) a full-strength Hoagland's solution [23] was added to the basil plants at $120 \%$ of the evapotranspiration each day, and (2) $50 \%$ of the full-strength Hoagland's solution was added to basil plants for the DS treatment.

\subsection{Phenology and Growth}

Basil plants from each treatment combination were harvested to obtain phenotype and growth data on early and late-stage growth effects of $\mathrm{DS}$ and $\mathrm{CO}_{2}$ at 17 and 38 days after treatment (DAT). Basil phenotypic data of Ht, node number (NN), branch number (BN), fresh mass (FM) were measured. Dry mass (DM) of the leaf (LDM), stem (SDM), root (RDM), shoot (ShDM), and whole plant (TDM) were measured for each treatment combination. Root to Shoot Ratio (RS) was measured using the ratio of RDM and ShDM.

LA was measured using the LI-3100 leaf-area meter (Li-Cor Bioscience, Lincoln, NE). Using a weighing scale, plant component FM was extracted from all basil plants. The plant FM samples were then dried for two days at $75^{\circ} \mathrm{C}$ in a forced-air oven to yield basil DM. The DM percent $(\mathrm{DM} \%)$ was calculated using (Shoot DM/FM) $\times 100 \%$.

\subsection{Root Image Acquisition and Analysis}

Roots were cut and separated from the stems and washed thoroughly. The total root length (TRL) was determined using a ruler. The cleaned individual root systems were floated in $5 \mathrm{~mm}$ of water in a 0.3 - by $0.2-\mathrm{m}$ Plexiglas tray. Roots were untangled and separated with a plastic paintbrush to minimize root overlap. The tray was placed on top of a specialized dual-scan optical scanner (Regent Instruments, Inc., Quebec, QC, Canada) linked to a computer. Gray-scale root images were acquired by setting the parameters to high accuracy (resolution $800 \times 800 \mathrm{dpi}$ ). Acquired images were analyzed for the lateral root length (LRL), root surface area (RSA), average root diameter (RAD), root volume (RV), number of root tips (RT), root forks (RF), and root crossings (RC) using WinRHIZO Pro software (Regent Instruments).

\subsection{Morpho-Physiological Measurements}

Leaf chlorophyll content (chlorophyll), epidermal flavonoids, epidermal anthocyanin, and nitrogen balance index (NBI) were measured on the second uppermost recently fully expanded leaf, second from the top, under each of three temperature treatments with a Dualex ${ }^{\circledR}$ Scientific Polyphenols and Chlorophyll Meter (FORCE-A, Orsay, France) at 38 DAT.

\subsection{Data Analysis}

Statistical analysis of the data was performed using SAS (version 9.4; SAS Institute, Cary, NC, USA). Data were analyzed using the PROC GLIMMIX analysis of variance (ANOVA) followed by mean separation. The experimental design was a randomized complete block in a factorial arrangement with two water and two $\mathrm{CO}_{2}$ treatments, threeblock, and ten replications. The standard errors were based on the pooled error term from the ANOVA table. Duncan's multiple range test $(p \leq 0.05)$ was used to differentiate treatment classifications when F values were significant for main effects. Model-based 
values were reported rather than the unequal standard error from a data-based calculation because pooled errors reflect the statistical testing. Diagnostic tests were conducted to ensure that treatment variances were statistically equal before pooling.

\section{Results and Discussion}

\subsection{Morphological Traits}

It is widely understood that basil thrives well under a 70\% soil water capacity [26]. Our result indicated that the DS (water supply at $50 \%$ or less than $50 \%$ soil water capacity) affects the Ht, LA, and FM, as well as several other basil's morphological traits. A report on basil demonstrated that TDM yield and Ht decreased by $31.6 \%$ and $26 \%$, respectively, due to DS [15]. Forouzandeh et al. [15] also reported several other morphological parameters such as that FM, ShDM, and RDM decreased by $42.2-60.1 \%$ under the DS with $60 \%$ soil water capacity in basil. Like DS, $\mathrm{eCO}_{2}$ is also considered an important environmental factor in affecting the economic yield of $\mathrm{C}_{3}$ plants such as basil [4]. Since these two factors occur concurrently, it is important to study the individual and combined factors to investigate potential interaction among factors. Morphological responses to DS in basil and most agronomic and horticultural crops include slow growth rate, reduced LA and LN, and increased RV and RS [27]. At $17 \mathrm{DAT}$, the interactive effect $(p<0.001)$ between DS $+\mathrm{eCO}_{2}$ as well as $\mathrm{DS}+\mathrm{aCO}_{2}$ was observed on the $\mathrm{Ht}$ (Table 1). There was a significant decrease in $\mathrm{Ht}$ by $9.6 \%(p<0.05)$ under DS $+\mathrm{aCO}_{2}$ compared to control on 17 DAT. However, there was no difference for $\mathrm{Ht}$ of DS $+\mathrm{eCO}_{2}$ compared to the control on $17 \mathrm{DAT}$. The decrease in $\mathrm{Ht}$ under DS $+\mathrm{aCO}_{2}$ and DS $+\mathrm{eCO}_{2}$ was observed by $16.8 \%$ and $10.6 \%$, respectively, on 38 DAT, compared to control. Previous research indicated that DS in commercial basil cultivars significantly reduced $\mathrm{Ht}$ [28]. However, the $\mathrm{eCO}_{2}$ can increase the $\mathrm{Ht}$ of basil by $8.5 \%$, as reported by Singh et al. [29]. Consequently, the observed reduction in $\mathrm{Ht}$ in this study may be due to the disturbance in the basil metabolic process leading to poor cell division and elongation [30].

Table 1. Dry mass percent (DM\%), plant height $(\mathrm{Ht})$, node number $(\mathrm{NN})$, branch number $(\mathrm{BN})$, and leaf area (LA) of basil plants grown without drought stress (Control) and with drought stress at two levels of $\mathrm{CO}_{2}$ (420 and $720 \mathrm{ppm}$ ) after 17 days of treatment.

\begin{tabular}{|c|c|c|c|c|c|}
\hline Treatment & DM\% ${ }^{1,3}$ & $\mathrm{Ht}$ & NN & BN & LA \\
\hline \multicolumn{6}{|c|}{$420 \mathrm{ppm}$} \\
\hline Control & $8.269^{b}$ & $36.56^{\mathrm{a}}$ & $7.1^{\mathrm{a}}$ & $15.33^{a}$ & $1223.60^{a b}$ \\
\hline Drought & $10.101^{\mathrm{ab}}$ & $33.05^{b}$ & $6.9^{a}$ & $13.56^{\mathrm{a}}$ & $997.72^{c}$ \\
\hline \multicolumn{6}{|c|}{720 ppm } \\
\hline Control & $8.981^{b}$ & $36.61^{a}$ & $7.0^{\mathrm{a}}$ & $15.33^{a}$ & $1321.09^{a}$ \\
\hline Drought & $11.823^{a}$ & $35.44^{\mathrm{a}}$ & $7.0^{\mathrm{a}}$ & $14.22^{\mathrm{a}}$ & $1070.67^{b c}$ \\
\hline Treatment ${ }^{2,4}$ & ** & $* * *$ & ns & * & $* * *$ \\
\hline $\mathrm{CO}_{2}$ & ns & * & ns & ns & ns \\
\hline Treatment $\times \mathrm{CO}_{2}$ & ns & * & ns & ns & ns \\
\hline
\end{tabular}

${ }^{1}$ Dry mass in percentage (\%); Height in centimeters (cm); Node number and branch number on a per plant basis Leaf area units in centimeters squared. ${ }^{2}$ Mean separation within the column by Duncan's multiple range tests $\mathrm{ns},{ }^{*}, * * * *$ indicates non-significant or significant at $p \leq 0.05,0.01$, and 0.001 , respectively. ${ }^{3}$ Values followed by the same letter are not significantly different. ${ }^{4}$ SE-Standard error of the mean, DM\% $=0.7, \mathrm{Ht}=0.6, \mathrm{NN}=0.1$, $\mathrm{BN}=0.8$, and $\mathrm{LA}=59.4$.

A previous study reported that DS reduced DM\% by $31.5 \%$ in basil $[15,28]$. On the other hand, Singh et al. [29] demonstrated that DM increases by $34.4 \%$ in basil treated with $800 \mathrm{ppm} \mathrm{CO}_{2}$. Moreover, $\mathrm{eCO}_{2}$ decreases stomatal conductance and increases photosynthetic rates, reducing transpiration and higher water use efficiency [31,32]. Also, it was reported that $\mathrm{CO}_{2}$ use becomes more efficient under DS when there is more supply of $\mathrm{CO}_{2}$ [33]. As reported earlier, an increase in water use efficiency under DS due to eCO also increases DM [34]. In support, $\mathrm{eCO}_{2}$ under DS is expected to start carbon fixation and prolong active growth by maintaining the soil water reserved for longer [35]. Likewise, in the current study, the DM\% increased significantly by $31.6 \%$ and $55.2 \%$ under $\mathrm{DS}+\mathrm{eCO}_{2}$ 
compared to control on 17 DAT and 38 DAT, respectively (Tables 1 and 2). Thus, it can be suggested that $\mathrm{eCO}_{2}$ ameliorated the adverse effect of DS on DM by increasing the water use efficiency in basil through more carbon assimilation, which leads to more biomass accumulation.

Table 2. Dry mass percent (DM\%), height $(\mathrm{Ht})$, node number $(\mathrm{NN})$, branch number $(\mathrm{BN})$, and leaf area (LA) of basil plants grown without drought stress (Control) and with drought stress at two levels of $\mathrm{CO}_{2}$ (420 and 720 ppm) after 38 days of treatment.

\begin{tabular}{|c|c|c|c|c|c|}
\hline Treatment & DM\% ${ }^{1,3}$ & $\mathbf{H t}$ & $\mathbf{N N}$ & $\mathrm{BN}$ & LA \\
\hline \multicolumn{6}{|c|}{420 ppm } \\
\hline Control & $11.733^{b}$ & $61.67^{\mathrm{a}}$ & $10.0^{\mathrm{a}}$ & $29.87^{\mathrm{a}}$ & $6946.3^{a}$ \\
\hline Drought & $16.265 \mathrm{a}$ & $51.27^{\mathrm{b}}$ & $9.8^{\mathrm{a}}$ & $31.27^{\mathrm{a}}$ & $3913.3^{b}$ \\
\hline \multicolumn{6}{|c|}{720 ppm } \\
\hline Control & $10.677^{b}$ & $60.93^{a}$ & $10.1^{\mathrm{a}}$ & $29.67^{\mathrm{a}}$ & $8078.9^{a}$ \\
\hline Drought & $16.571^{a}$ & $54.47^{\mathrm{b}}$ & $10.0^{\mathrm{a}}$ & $29.67^{\mathrm{a}}$ & $3978.7^{b}$ \\
\hline Treatment 2,4 & $* * *$ & $* * *$ & ns & ns & $* * *$ \\
\hline $\mathrm{CO}_{2}$ & ns & ns & ns & ns & ns \\
\hline Treatment $\times \mathrm{CO}_{2}$ & ns & ns & ns & ns & ns \\
\hline
\end{tabular}

${ }^{1}$ Dry mass in percentage (\%); Height in centimeters $(\mathrm{cm})$; Node number and branch number on a per plant basis; Leaf area units in centimeters squared. ${ }^{2}$ Mean separation within the column by Duncan's multiple range test; ns and ${ }^{* * *}$ indicates non-significant or significant at $p \leq 0.05$ and 0.001 , respectively; ${ }^{3}$ Values followed by the same letter are not significantly different. ${ }^{4}$ SE-Standard error of the mean, DM\% $=0.5, \mathrm{Ht}=1.7, \mathrm{NN}=0.1, \mathrm{BN}=1.1$, and $\mathrm{LA}=581.36$.

The leaf is considered the most drought-sensitive part of the plant [31]. It is also responsible for reducing water loss and promoting water use efficiency during DS [36]. In the current study, LA decreased by $19 \%$ under both $\mathrm{DS}+\mathrm{aCO}_{2}$ and $\mathrm{DS}+\mathrm{eCO}_{2}$ treatment on 17 DAT compared to control. Similarly, LA decreased by $43.6 \%$ and $50.8 \%$ under both $\mathrm{DS}+\mathrm{aCO}_{2}$ and DS $+\mathrm{eCO}_{2}$ treatment on $38 \mathrm{DAT}$ compared to control. Previous research indicated that basil LA decreased under DS [37]. Similarly, an experiment conducted on sunflowers also demonstrated a significant reduction in LA under the DS [38].

Conversely, different fruits, vegetables, basil, and several other $\mathrm{C}_{3}$ plants treated with $\mathrm{eCO}_{2}$ have demonstrated an increase in LA [29]. In the present study, $\mathrm{eCO}_{2}$ fails to amend the effect of DS on LA, further supported by soybean reports [39]. In plants subjected to DS, their cell weakens, leading to low water potential and low turgor pressure and, ultimately, reduced growth [28], thus demonstrating that these factors are behind LA's reduction in basil [40].

In the current study, basil FM was also significantly $(p<0.01)$ reduced under the $\mathrm{DS}+\mathrm{aCO}_{2}$ and $\mathrm{DS}+\mathrm{eCO}_{2}$ treatment at $17 \mathrm{DAT}$ and $38 \mathrm{DAT}$, which is further supported by previous research on basil [41]. It is worth noting that $\mathrm{FM}$ was highest under control condition at $\mathrm{eCO}_{2}$ level and was lowest under DS at both $\mathrm{CO}_{2}$ levels on 17 and 38 DAT (Tables 3 and 4). It is important to note that the water retention under DS $+\mathrm{eCO}_{2}$ in the later season was poor, as shown in Table 4. A study in cork oak by Vaz et al. [42] reported that the effect of $\mathrm{eCO}_{2}$ can deteriorate under any stress in the long run, which can make a difference in leaf morphology. 
Table 3. Fresh mass (FM), leaf dry mass (LDM), stem dry mass (SDM), root dry mass (RDM), shoot dry mass (ShDM), total dry mass (TDM), and root-to-shoot ratio (RS) of basil plants grown under without drought stress (Control) and with drought stress at two levels of $\mathrm{CO}_{2}$ (420 and $720 \mathrm{ppm}$ ) after 17 days of treatment.

\begin{tabular}{|c|c|c|c|c|c|c|c|}
\hline Treatment & FM $^{1,4}$ & LDM & SDM & RDM & ShDM & TDM & $\mathrm{RS}^{2}$ \\
\hline \multicolumn{8}{|c|}{420 ppm } \\
\hline Control & $80.62^{b}$ & $4.479 \mathrm{bc}$ & $2.188^{b c}$ & $0.941^{\mathrm{a}}$ & $6.667^{b c}$ & $7.608^{b c}$ & $0.140^{b c}$ \\
\hline Drought & $59.32^{\mathrm{C}}$ & $3.987^{c}$ & $\begin{array}{l}2.021^{\mathrm{c}} \\
720 \mathrm{ppm}\end{array}$ & $1.066^{\mathrm{a}}$ & $6.008^{c}$ & $7.073^{c}$ & $0.176^{\mathrm{a}}$ \\
\hline Control & $94.37^{\mathrm{a}}$ & $5.779^{a}$ & $2.789^{\mathrm{a}^{\mathrm{1}}}$ & $1.021^{\mathrm{a}}$ & $8.568^{a}$ & $9.589^{a}$ & $0.119^{c}$ \\
\hline Drought & $67.94^{c}$ & $5.074^{\mathrm{ab}}$ & $2.642^{a b}$ & $1.180^{\mathrm{a}}$ & $7.717^{\mathrm{ab}}$ & $8.897^{a b}$ & $0.163^{a b}$ \\
\hline Treatment $^{3,5}$ & $* * *$ & ns & ns & ns & ns & ns & $* *$ \\
\hline $\mathrm{CO}_{2}$ & $* *$ & $* *$ & $* *$ & ns & $* *$ & $* *$ & ns \\
\hline Treatment $\times \mathrm{CO}_{2}$ & ns & ns & ns & ns & ns & ns & ns \\
\hline
\end{tabular}

${ }^{1}$ Fresh weight, leaf dry weight, stem dry weight, root dry weight, shoot dry weight, and total dry weight units on a gram per plant basis. ${ }^{2}$ RS- Root to Shoot Ratio (Root Dry Mass/Shoot Dry Mass) ${ }^{3}$ Mean separation within the column by Duncan's multiple range test; ns, ${ }^{* *},{ }^{* * *}$ indicates non-significant or significant at $p \leq 0.05,0.01$, and 0.001 , respectively. ${ }^{4}$ Values followed by the same letter are not significantly different. ${ }^{5}$ SE-Standard error of the mean, $\mathrm{FM}=3.9 ; \mathrm{LDM}=0.3 ; \mathrm{SDM}=0.2 ; \mathrm{RDM}=0.1 ; \mathrm{ShDM}=0.5 ; \mathrm{TDM}=0.5 ; \mathrm{RS}$ ratio $=0.01$.

Table 4. Fresh mass (FM), leaf dry mass (LDM), stem dry mass (SDM), root dry mass (RDM), shoot dry mass (ShDM), total dry mass (TDM), and root-to-shoot ratio (RS) of basil plants grown under without drought stress (Control) and with drought stress at two levels of $\mathrm{CO}_{2}$ (420 and $\left.720 \mathrm{ppm}\right)$ after 38 days of treatment.

\begin{tabular}{|c|c|c|c|c|c|c|c|}
\hline Treatment & $\mathrm{FM}^{1,4}$ & LDM & SDM & RDM & ShDM & TDM & $\mathrm{RS}^{2}$ \\
\hline \multicolumn{8}{|c|}{420 ppm } \\
\hline Control & $486.33^{b}$ & $25.032^{\mathrm{a}}$ & $33.049 \mathrm{ab}$ & $6.840^{\mathrm{ab}}$ & $58.081 \mathrm{ab}$ & $64.922^{a b}$ & $0.116^{b}$ \\
\hline Drought & $284.30^{c}$ & $17.591^{\mathrm{b}}$ & $\begin{array}{l}27.591^{\mathrm{b}} \\
720 \mathrm{ppm}\end{array}$ & $5.343^{b}$ & $45.182^{b}$ & $50.525^{b}$ & $0.120^{b}$ \\
\hline Control & $613.71^{\mathrm{a}}$ & $28.393^{\mathrm{a}}$ & $38.733^{\mathrm{a}}$ & $8.511^{a}$ & $67.126^{\mathrm{a}}$ & $75.637^{\mathrm{a}}$ & $0.128^{a b}$ \\
\hline Drought & $275.46^{c}$ & $17.060^{\mathrm{b}}$ & $29.756^{b}$ & $6.388^{b}$ & $46.816^{b}$ & $53.204^{b}$ & $0.140^{\mathrm{a}}$ \\
\hline Treatment 3,5 & $* * *$ & $* * *$ & * & $* *$ & $* *$ & ** & ns \\
\hline $\mathrm{CO}_{2}$ & ns & ns & ns & * & ns & ns & * \\
\hline Treatment $\times \mathrm{CO}_{2}$ & ns & ns & ns & ns & ns & ns & ns \\
\hline
\end{tabular}

${ }^{1}$ Fresh weight, leaf dry weight, stem dry weight, root dry weight, shoot dry weight, and total dry weight units on a gram per plant basis. ${ }^{2}$ RS- Root to Shoot Ratio (Root Dry Mass/Shoot Dry Mass) ${ }^{3}$ Mean separation within the column by Duncan's multiple range test; ns, ${ }^{*}, * * * * *$ indicates non-significant or significant at $p \leq 0.05,0.01$, and 0.001 , respectively. ${ }^{4}$ Values followed by the same letter are not significantly different. ${ }^{5}$ SE-Standard error of the mean, $\mathrm{FM}=38.2 ; \mathrm{LDM}=2.1 ; \mathrm{SDM}=3.0 ; \mathrm{RDM}=0.7 ; \mathrm{ShDM}=5.0 ; \mathrm{TDM}=5.7 ; \mathrm{RS}$ ratio $=0.006$.

Other the other hand, a previous study demonstrated an increase in FM in basil by $54.1 \%$ under $\mathrm{eCO}_{2}(827 \mathrm{ppm})+$ non-drought conditions (control) [43]. O'Leary et al. [43] also reported that, although $\mathrm{eCO}_{2}$ helps to mitigate the negative effect of DS on FM through improved water use efficiency, $\mathrm{eCO}_{2}$ always performs better under water-sufficient conditions ( $>70 \%$ soil water capacity). For this reason, FM was recorded the lowest under DS at both $\mathrm{CO}_{2}$ levels in this study.

TDM and yield were reduced by $34 \%$ under deficit irrigation in different basil cultivars [26]. However, in our study, there was no interaction between DS and $\mathrm{CO}_{2}$ treatments when analyzing DM\%, NN, BN, LDM, SDM, RDM, ShDM, and RS compared to the control treatment on 17 DAT (Tables 1 and 3). On 38 DAT, there was no interaction effect between DS and $\mathrm{CO}_{2}$ treatments on any morphological parameters (Table 4).

The root system is responsible for absorbing water and nutrients from the soil, and it plays an essential role in the plant's response to DS [36]. Some $C_{3}$ and $C_{4}$ plants have the robust ability to increase root growth at the early stage of DS to absorb water from the deep soil [44]. This suggests that the density, length, volume, and mass of roots are directly associated with crop DS resistance $[45,46]$. The root tissues were measured at 17 DAT (Table 5). However, none of the parameters (LRL, TRL, RSA, RAD, RV, RT, RF, or $\mathrm{RC}$ showed the interactive effects of the $\mathrm{DS}$ and $\mathrm{CO}_{2}$ treatments. A treatment effect 
$(p<0.01)$ was observed in LRL, where there was a significant decrease in LRL by $13.5 \%$ under DS $+\mathrm{eCO}_{2}$ compared to control at $17 \mathrm{DAT}$. Interestingly, RV, RT, RF, and RC increased by $13-20 \%$ under $\mathrm{DS}+\mathrm{eCO}_{2}$ than control under $\mathrm{aCO}_{2}$. A report on cucumber demonstrated that an increasing $\mathrm{CO}_{2}$ level from 400 to $1200 \mathrm{ppm}$ increases RV and RT by 6-8\% [47]. In a review by Rogers et al. [48], approximately 150 studies concluded that $92 \%$ of root growth increased with $\mathrm{eCO}_{2}$, further supporting the current study's result.

Table 5. The mean of lateral root length (LRL), total root length (TRL), root surface area (RSA), average root diameter (RAD), root volume (RV), root tips (RT), root forks (RF), and root crossings (RC) of basil plants grown under without drought stress (Control) and with drought stress at two levels of $\mathrm{CO}_{2}$ (420 and 720 ppm) after 17 days of treatment.

\begin{tabular}{|c|c|c|c|c|c|c|c|c|}
\hline Treatment & LRL $^{1,3}$ & TRL & RSA & RAD & RV & RT & RF & RC \\
\hline & \multicolumn{8}{|c|}{420 ppm } \\
\hline Control & $45.1^{\mathrm{a}}$ & $4572.9^{\mathrm{a}}$ & $854.3^{a}$ & $0.597^{\mathrm{a}}$ & $14.00^{b}$ & $10,052^{b}$ & $38,545^{\mathrm{b}}$ & $2412.6^{b}$ \\
\hline Drought & $43.0^{\mathrm{ab}}$ & $4230.7^{\mathrm{a}}$ & $729.5^{a}$ & $0.547^{\mathrm{a}}$ & $13.73^{b}$ & $14,347^{\mathrm{a}}$ & $44,146^{\mathrm{b}}$ & $3255.8^{a b}$ \\
\hline & \multicolumn{8}{|c|}{720 ppm } \\
\hline Control & $46.7^{\mathrm{a}}$ & $4159.1^{\mathrm{a}}$ & $738.6^{a}$ & $0.560^{\mathrm{a}}$ & $15.45^{\mathrm{ab}}$ & $12,477 \mathrm{ab}$ & $46,580^{a b}$ & $3287.8^{a b}$ \\
\hline Drought & $40.4^{b}$ & $4265.6^{\mathrm{a}}$ & $765.1^{a}$ & $0.574^{\mathrm{a}}$ & $17.60^{\mathrm{a}}$ & $15,042^{\mathrm{a}}$ & $55,344^{\mathrm{a}}$ & $3840.4^{\mathrm{a}}$ \\
\hline Treatment 2,4 & $* *$ & ns & ns & ns & ns & * & ns & ns \\
\hline $\mathrm{CO}_{2}$ & ns & ns & ns & ns & * & ns & $*$ & $*$ \\
\hline Treatment $\times \mathrm{CO}_{2}$ & ns & ns & ns & ns & ns & ns & ns & ns \\
\hline
\end{tabular}

${ }^{1}$ Lateral root length, total root length, and root average diameter on a centimeter per plant basis; root surface area, root volume on a cubic centimeter basis; root tips, root forks, and root crossings on a number per plant basis. ${ }^{2}$ Mean separation within the column by Duncan's multiple range test; $\mathrm{ns},{ }^{*},{ }^{* *}$ indicates non-significant or significant at $p \leq 0.05,0.01$, and 0.001 , respectively. ${ }^{3}$ Values followed by the same letter are not significantly different. ${ }^{4} \mathrm{SE}-\mathrm{Standard}$ error of the mean, $\mathrm{LRL}=1.5 ; \mathrm{TRL}=258.3 ; \mathrm{RSA}=52.9 ; \mathrm{RAD}=0.02 ; \mathrm{RV}=1.3 ; \mathrm{RT}=1723.8$; $\mathrm{RF}=4462.6 ; \mathrm{RC}=370.2$.

\subsection{Physiological Measurements}

Drought is a significant factor for damaging the photosynthetic pigments and thylakoid membranes [49]. DS also inhibits plants' photosynthetic apparatuses by declining $\mathrm{CO}_{2}$ availability and stomatal closure [50]. To study basil's leaf physiology changes under DS, different physiological parameters such as chlorophyll content, flavonoids, anthocyanin, and NBI were measured (Table 6). Flavonoid is a ubiquitous secondary metabolite in plants, which helps to protect the plant from abiotic and biotic stresses, while anthocyanin reduces the damage caused by free radical activity [51]. Both anthocyanin and flavonoid compounds are responsible for antioxidant activity in plants [52]. Both compounds increased under the $\mathrm{DS}+\mathrm{eCO}_{2}$ conditions [53,54]. However, in the present findings, the flavonoid was indifferent to the control treatment under the $\mathrm{DS}+\mathrm{eCO}_{2}$ condition, which contradicts the earlier report on basil by Al Jaouni et al. [4]. Previous research demonstrated that anthocyanin decreased under $\mathrm{DS}+\mathrm{aCO}_{2}$ but increased under $\mathrm{DS}+\mathrm{eCO}_{2}[53,55]$. These reports support the recent finding where anthocyanin decreased by $10 \%$ in $\mathrm{DS}+\mathrm{aCO}_{2}$ and increased by $12.6 \%$ in DS $+\mathrm{eCO}_{2}$ compared to control. Similarly, NBI, a ratio of chlorophyll and flavonoid, was measured, and it was recorded to be the highest in $\mathrm{DS}+\mathrm{aCO}_{2}$ (40.8) compared to any other treatments. A study by Taub and Wang [56] reported that plants grown under $\mathrm{eCO}_{2}$ had decreased nitrogen concentration compared to plants grown under $\mathrm{aCO}_{2}$. 
Table 6. The mean of leaf chlorophyll, flavonoid, anthocyanin, and nitrogen balance index (NBI) of basil plants grown without drought stress (control) and with drought stress at two levels of $\mathrm{CO}_{2}$ (420 and 720 ppm) after 17 days of treatment.

\begin{tabular}{|c|c|c|c|c|}
\hline Treatment & Chlorophyll ${ }^{3}$ & Flavonoids & Anthocyanin & NBI $^{1}$ \\
\hline & {$\left[\mu \mathrm{g} \cdot \mathrm{mL}^{-1}\right]$} & {$\left[\mathrm{mg} \cdot \mathrm{g}^{-1} \mathrm{DM}\right]$} & {$\left[\mathrm{mg} \cdot \mathrm{g}^{-1} \mathrm{DM}\right]$} & \\
\hline & & 420 ppm & & \\
\hline Control & $21.468^{b c}$ & $0.6853^{a b}$ & $0.1144^{b}$ & $32.415^{b}$ \\
\hline \multirow[t]{2}{*}{ Drought } & $25.744^{\mathrm{a}}$ & $0.6455^{b}$ & $0.1028^{c}$ & $40.890^{\mathrm{a}}$ \\
\hline & & 720 ppm & & \\
\hline Control & $18.978^{c}$ & $0.7044^{\mathrm{ab}}$ & $0.1126^{b c}$ & $28.062^{c}$ \\
\hline Drought & $22.027^{b}$ & $0.7394^{\mathrm{a}}$ & $0.1269^{a}$ & $30.391^{b c}$ \\
\hline Treatment ${ }^{2,4}$ & $* * *$ & ns & $* * *$ & $* * *$ \\
\hline $\mathrm{CO}_{2}$ & $* *$ & $*$ & $* *$ & $* * *$ \\
\hline Treatment $\times \mathrm{CO}_{2}$ & ns & ns & ns & * \\
\hline
\end{tabular}

${ }^{1}$ NBI-Nitrogen Balance Index (a ratio of chlorophyll and flavonoid). ${ }^{2}$ Mean separation within the column by Duncan's multiple range test; $\mathrm{ns},{ }^{*}, * *, * *$ indicate non-significant or significant at $p \leq 0.05,0.01,0.001$, respectively. ${ }^{3}$ Values followed by the same letter are not significantly different. ${ }^{4}$ SE-Standard error of the mean, Chlorophyll $=0.9 ;$ Flavonoid $=0.03$; Anthocyanin $=0.04 ; \mathrm{NBI}=1.600$.

Similarly, DS is also responsible for decreasing the nitrogen isotope composition and the transient decrease in chlorophyll, which increases the accumulation of anthocyanin [57]. In the present study, chlorophyll increased by $20 \%$ and $16 \%$ under DS when $\mathrm{aCO}_{2}$ and $\mathrm{eCO}_{2}$ were applied, respectively, compared to control. In brief, $\mathrm{DS}+\mathrm{eCO}_{2}$ promotes chlorophyll and inhibits NBI, increasing the accumulation of anthocyanin.

\section{Conclusions}

This study provides evidence that $\mathrm{DS}+\mathrm{eCO}_{2}$ has a significant positive impact on basil's overall morphology. $\mathrm{eCO}_{2}$ remarkably reduced the negative effect of DS by promoting several morphological traits such as DM, RV, RT, RF, and RC. The DS had a severe impact on several morphological traits comprising both shoot and root systems. Compared to control, the DS reduces the marketable FM remarkably by $31.6 \%$ and $55.2 \%$ in the early and late basil season. FM is the highest under control $+\mathrm{eCO}_{2}(94.4-613.7 \mathrm{~g})$, while it was the lowest under DS $+\mathrm{aCO}_{2}(67.9-275.5 \mathrm{~g})$. Similarly, $\mathrm{Ht}$ reduction under DS $+\mathrm{eCO}_{2}$ $(10.6 \%)$ is significantly lower than $\mathrm{DS}+\mathrm{aCO}_{2}(16.8 \%)$ during the late season. DM increases by $31.6 \%$ and $55.2 \%$ under DS $+\mathrm{eCO}_{2}$ compared to control in the early and late season, respectively.

This study suggests that $\mathrm{eCO}_{2}$ during DS has a more significant positive effect on basil morphological traits than $\mathrm{CO}_{2}$. Also, $\mathrm{eCO}_{2}$ positively impacted and increased the $\mathrm{NBI}$ and chlorophyll by alleviating the negative impact of DS. Conversely, $\mathrm{eCO}_{2}$ failed to lessen the adverse effect of DS on FM, LA, and Ht. Overall, this study indicates that DS impacted the basil more strongly in the late rather than in the early season, and $\mathrm{eCO}_{2}$ in the late season has a more significant impact on some basil's morphological traits such as LA, FM, RDM, ShDM, and TDM than $\mathrm{aCO}_{2}$.

Author Contributions: T.C.B.: conceptualization, methodology, validation, formal analysis, investigation, resources, data curation, writing — original draft, writing — review \& editing, visualization, supervision, project administration, funding acquisition. B.A.: formal analysis, writing - original draft, writing-review \& editing. A.S.: methodology, validation, investigation. C.H.W.: methodology, validation, formal analysis, investigation. K.R.R.: conceptualization, methodology, validation, formal analysis, investigation, resources, data curation, writing - review \& editing, visualization, supervision, project administration, funding acquisition. W.G.: conceptualization, methodology, validation, resources, funding acquisition. All authors have read and agreed to the published version of the manuscript.

Funding: This material is based on the work supported by the USDA-NIFA Hatch Project under accession number 149210, and the National Institute of Food and Agriculture, 2019-34263-30552, and MIS 043050 funded this research. 
Institutional Review Board Statement: Not applicable.

Informed Consent Statement: Not applicable.

Data Availability Statement: The data presented in this study are available on request from the corresponding author.

Acknowledgments: We thank David Brand for technical assistance and graduate students at the Environmental Plant Physiology Laboratory for their help during data collection. We would also like to thank Thomas Horgan for his technical assistance on the project.

Conflicts of Interest: The authors declare that they have no known competing financial interests or personal relationships that could have appeared to influence the work reported in this paper.

\section{References}

1. Vanli, Ö.; Ustundag, B.B.; Ahmad, I.; Hernandez-Ochoa, I.M.; Hoogenboom, G. Using crop modeling to evaluate the impacts of climate change on wheat in southeastern turkey. Environ. Sci. Pollut. Res. 2019, 26, 29397-29408. [CrossRef] [PubMed]

2. $\quad$ IPCC Climate change 2007: The physical science basis. Agenda 2007, 6, 333.

3. Stocker, T.F.; Qin, D.; Plattner, G.-K.; Tignor, M.M.B.; Allen, S.K.; Boschung, J.; Nauels, A.; Xia, Y.; Bex, V.; Midgley, P.M. Climate Change 2013: The Physical Science Basis; Contribution of Working Group I to the fifth Assessment Report of the Intergovernmental Panel on Climate Change; IPCC: Cambridge, UK; New York, NY, USA,, 2013; Available online: https://www.ipcc.ch/site/assets/ uploads/2017/09/WG1AR5_Frontmatter_FINAL.pdf (accessed on 27 October 2021).

4. Al-Jaouni, S.; Saleh, A.M.; Wadaan, M.A.M.; Hozzein, W.N.; Selim, S.; AbdElgawad, H. Elevated $\mathrm{CO}_{2}$ induces a global metabolic change in basil (Ocimum basilicum L.) and peppermint (Mentha piperita L.) and improves their biological activity. J. Plant Physiol. 2018, 224, 121-131. [CrossRef]

5. Savo, V.; Lepofsky, D.; Benner, J.P.; Kohfeld, K.E.; Bailey, J.; Lertzman, K. Observations of climate change among subsistenceoriented communities around the world. Nat. Clim. Chang. 2016, 6, 462-473. [CrossRef]

6. Damalas, C.A. Improving drought tolerance in sweet basil (Ocimum basilicum) with salicylic acid. Sci. Hortic. 2019, 246, 360-365 [CrossRef]

7. Haile, G.G.; Tang, Q.; Hosseini-Moghari, S.; Liu, X.; Gebremicael, T.G.; Leng, G.; Kebede, A.; Xu, X.; Yun, X. Projected impacts of climate change on drought patterns over East Africa. Earth's Future 2020, 8, e2020EF001502. [CrossRef]

8. Jehanzaib, M.; Kim, T.-W. Exploring the influence of climate change-induced drought propagation on wetlands. Ecol. Eng. 2020, 149, 105799. [CrossRef]

9. Ahmed, E.A.; Hassan, E.A.; El Tobgy, K.M.K.; Ramadan, E.M. Evaluation of rhizobacteria of some medicinal plants for plant growth promotion and biological control. Ann. Agric. Sci. 2014, 59, 273-280. [CrossRef]

10. Mijani, S.; Nasrabadi, S.E.; Zarghani, H.; Abadi, M.G. Seed germination and early growth responses of hyssop, sweet basil and oregano to temperature levels. Not. Sci. Biol. 2013, 5, 462-467. [CrossRef]

11. Ekren, S.; Sönmez, Ç.; Özçakal, E.; Kurttaş, Y.S.K.; Bayram, E.; Gürgülü, H. The effect of different irrigation water levels on yield and quality characteristics of purple basil (Ocimum basilicum L.). Agric. Water Manag. 2012, 109, 155-161. [CrossRef]

12. Alishah, H.M.; Heidari, R.; Hassani, A.; Asadi, D.A. Effect of water stress on Some Morphological and Biochemical Characteristics of Purple Basil (Ocimum basilicum). J. Biol. Sci. 2006, 6, 763-767.

13. Rahbarian, R.; Khavari-Nejad, R.; Ganjeali, A.; Bagheri, A.; Najafi, F. Drought stress effects on photosynthesis, chlorophyll fluorescence and water relations in tolerant and susceptible chickpea (Cicer arietinum L.) genotypes. Acta Biol. Cracoviensia. Ser. Bot. 2011, 53, 47-56. [CrossRef]

14. Safikhani, F.; Sharifabadi, H.H.; Siadat, S.A.; Ashoorabadi, A.S.; Seyyednejad, S.M.; Abbaszadeh, B. Effects of drought stress on yield and morphological traits of dragonhead (Dracocephalum moldavica L.). Iran. J. Med. Aromat. Plants 2007, 23, 183-194.

15. Forouzandeh, M.; Fanoudi, M.; Arazmjou, E.; Tabiei, H. Effect of drought stress and types of fertilizers on the quantity and quality of medicinal plant Basil (Ocimum basilicum L.). Indian J. Innov. Dev. 2012, 1, 696-699.

16. Saleh, A.M.; Selim, S.; Al Jaouni, S.; AbdElgawad, H. $\mathrm{CO}_{2}$ enrichment can enhance the nutritional and health benefits of parsley (Petroselinum crispum L.) and dill (Anethum graveolens L.). Food Chem. 2018, 269, 519-526. [CrossRef] [PubMed]

17. Dong, J.; Gruda, N.; Li, X.; Tang, Y.; Zhang, P.; Duan, Z. Sustainable vegetable production under changing climate: The impact of elevated $\mathrm{CO}_{2}$ on yield of vegetables and the interactions with environments-A review. J. Clean. Prod. 2020, 253, 119920. [CrossRef]

18. Zhao, X.; Mao, Z.; Xu, J. Gas exchange, chlorophyll and growth responses of Betula platyphylla seedlings to elevated $\mathrm{CO}_{2}$ and nitrogen. Int. J. Biol. 2010, 2, 143. [CrossRef]

19. Ghanbari, A.; Abedi, K.; Taie, S. Effect of municipal wastewater irrigation on yield and quality of wheat and some soil properties in sistan zone. J. Sci. Technol. Agric. Nat. Resour. 2007, 10, 513-528.

20. Sharp, R.E.; Poroyko, V.; Hejlek, L.G.; Spollen, W.G.; Springer, G.K.; Bohnert, H.J.; Nguyen, H.T. Root growth maintenance during water deficits: Physiology to functional genomics. J. Exp. Bot. 2004, 55, 2343-2351. [CrossRef]

21. Reddy, K.R.; Hodges, H.F.; Read, J.J.; McKinion, J.M.; Baker, J.T.; Tarpley, L.; Reddy, V.R. Soil-Plant-Atmosphere-Research (SPAR) facility: A tool for plant research and modeling. Biotronics 2001, 30, $27-50$. 
22. Wijewardana, C.; Hock, M.; Henry, B.; Reddy, K.R. Screening corn hybrids for cold tolerance using morphological traits for early-season seeding. Crop Sci. 2015, 55, 851-867. [CrossRef]

23. Hoagland, D.R.; Arnon, D.I. The Water-Culture Method for Growing Plants without Soil; College of Agriculture, University of California: Davis, CA, USA, 1950; 347p.

24. McKinion, J.M.; Hodges, H.F. Automated system for measurement of evapotranspiration from closed environmental growth chambers. Trans. ASAE 1985, 28, 1825-1828. [CrossRef]

25. Timlin, D.; Fleisher, D.; Kim, S.; Reddy, V.; Baker, J. Evapotranspiration measurement in controlled environment chambers: A comparison between time domain reflectometry and accumulation of condensate from cooling coils. Agron. J. 2007, 99, 166-173. [CrossRef]

26. Radácsi, P.; Inotai, K.; Sárosi, S.; Czövek, P.; Bernath, J.; Nemeth, E. Effect of water supply on the physiological characteristic and production of basil (Ocimum basilicum L.). Eur. J. Hortic. Sci. 2010, 75, 193.

27. Osakabe, Y.; Osakabe, K.; Shinozaki, K.; Tran, L.-S.P. Response of plants to water stress. Front. Plant Sci. 2014, 5, 86. [CrossRef] [PubMed]

28. Sirousmehr, A.; Arbabi, J.; Asgharipour, M.R. Effect of drought stress levels and organic manures on yield, essential oil content and some morphological characteristics of sweet basil (Ocimum basilicum). Adv. Environ. Biol. 2014, 8, 880-885.

29. Singh, H.; Poudel, M.R.; Dunn, B.L.; Fontanier, C.; Kakani, G. Effect of greenhouse $\mathrm{CO}_{2}$ supplementation on yield and mineral element concentrations of leafy greens grown using nutrient film technique. Agronomy 2020, 10, 323. [CrossRef]

30. Kordi, S.; Saidi, M.; Ghanbari, F. Induction of drought tolerance in sweet basil (Ocimum basilicum L.) by salicylic acid. Int. J. Agric. Food Res. 2013, 2, 18-26. [CrossRef]

31. Barickman, T.C.; Adhikari, B.; Sehgal, A.; Walne, C.H.; Reddy, K.R. Drought and elevated $\mathrm{CO}_{2}$ impacts photosynthesis and biochemicals of basil (Ocimum basilicum L.). Stresses 2021, 1, 223-237. [CrossRef]

32. Long, S.P.; Ainsworth, E.A.; Rogers, A.; Ort, D.R. Rising atmospheric carbon dioxide: Plants FACE the future. Annu. Rev. Plant Biol. 2004, 55, 591-628. [CrossRef]

33. Zhang, J.; Jiang, H.; Song, X.; Jin, J.; Zhang, X. The responses of plant leaf $\mathrm{CO}_{2} / \mathrm{H}_{2} \mathrm{O}$ exchange and water use efficiency to drought: A meta-analysis. Sustainability 2018, 10, 551. [CrossRef]

34. Ayub, G.; Smith, R.A.; Tissue, D.T.; Atkin, O.K. Impacts of drought on leaf respiration in darkness and light in Eucalyptus saligna exposed to industrial-age atmospheric $\mathrm{CO}_{2}$ and growth temperature. New Phytol. 2011, 190, 1003-1018. [CrossRef]

35. Reyes-Fox, M.; Steltzer, H.; Trlica, M.J.; McMaster, G.S.; Andales, A.A.; LeCain, D.R.; Morgan, J.A. Elevated CO 2 further lengthens growing season under warming conditions. Nature 2014, 510, 259-262. [CrossRef]

36. Fang, Y.; Xiong, L. General mechanisms of drought response and their application in drought resistance improvement in plants. Cell. Mol. Life Sci. 2015, 72, 673-689. [CrossRef] [PubMed]

37. Asgharipour, M.; Rafiei, M. Effect of different organic amendments and drought on the growth and yield of basil in the greenhouse. Adv. Environ. Biol. 2011, 1233-1240.

38. Misra, A.; Srivastava, N.K. Influence of water stress on Japanese mint. J. Herbs. Spices Med. Plants 2000, 7, 51-58. [CrossRef]

39. Li, D.; Liu, H.; Qiao, Y.; Wang, Y.; Cai, Z.; Dong, B.; Shi, C.; Liu, Y.; Li, X.; Liu, M. Effects of elevated $\mathrm{CO}_{2}$ on the growth, seed yield, and water use efficiency of soybean (Glycine max (L.) Merr.) under drought stress. Agric. Water Manag. 2013, 129, 105-112. [CrossRef]

40. Sumner, M.E. Beneficial use of effluents, wastes, and biosolids. Commun. Soil Sci. Plant Anal. 2000, 31, 1701-1715. [CrossRef]

41. Pirbalouti, A.G.; Malekpoor, F.; Salimi, A.; Golparvar, A. Exogenous application of chitosan on biochemical and physiological characteristics, phenolic content and antioxidant activity of two species of basil (Ocimum ciliatum and Ocimum basilicum) under reduced irrigation. Sci. Hortic. 2017, 217, 114-122. [CrossRef]

42. Vaz, M.; Cochard, H.; Gazarini, L.; Graça, J.; Chaves, M.M.; Pereira, J.S. Cork oak (Quercus suber L.) seedlings acclimate to elevated $\mathrm{CO}_{2}$ and water stress: Photosynthesis, growth, wood anatomy and hydraulic conductivity. Trees 2012, 26, 1145-1157. [CrossRef]

43. O'Leary, G.J.; Christy, B.; Nuttall, J.; Huth, N.; Cammarano, D.; Stöckle, C.; Basso, B.; Shcherbak, I.; Fitzgerald, G.; Luo, Q. Response of wheat growth, grain yield and water use to elevated $\mathrm{CO}_{2}$ under a Free-Air $\mathrm{CO}_{2}$ Enrichment (FACE) experiment and modelling in a semi-arid environment. Glob. Chang. Biol. 2015, 21, 2670-2686. [CrossRef]

44. Hu, H.; Xiong, L. Genetic engineering and breeding of drought-resistant crops. Annu. Rev. Plant Biol. 2014, 65, 715-741. [CrossRef] [PubMed]

45. Forster, B.P.; Thomas, W.T.B.; Chloupek, O. Genetic controls of barley root systems and their associations with plant performance. Asp. Appl. Biol. 2005, 73, 199-204.

46. Hammer, G.L.; Dong, Z.; McLean, G.; Doherty, A.; Messina, C.; Schussler, J.; Zinselmeier, C.; Paszkiewicz, S.; Cooper, M. Can changes in canopy and/or root system architecture explain historical maize yield trends in the US corn belt? Crop Sci. 2009, 49, 299-312. [CrossRef]

47. Li, X.; Dong, J.; Chu, W.; Chen, Y.; Duan, Z. The relationship between root exudation properties and root morphological traits of cucumber grown under different nitrogen supplies and atmospheric $\mathrm{CO}_{2}$ concentrations. Plant Soil 2018, 425, 415-432. [CrossRef]

48. Rogers, H.H.; Runion, G.B.; Krupa, S. V Plant responses to atmospheric $\mathrm{CO}_{2}$ enrichment with emphasis on roots and the rhizosphere. Environ. Pollut. 1994, 83, 155-189. [CrossRef]

49. Anjum, S.A.; Wang, L.C.; Farooq, M.; Hussain, M.; Xue, L.L.; Zou, C.M. Brassinolide application improves the drought tolerance in maize through modulation of enzymatic antioxidants and leaf gas exchange. J. Agron. Crop Sci. 2011, 197, 177-185. [CrossRef] 
50. Chaves, M.M.; Flexas, J.; Pinheiro, C. Photosynthesis under drought and salt stress: Regulation mechanisms from whole plant to cell. Ann. Bot. 2009, 103, 551-560. [CrossRef] [PubMed]

51. El Kelish, A.; Zhao, F.; Heller, W.; Durner, J.; Winkler, J.B.; Behrendt, H.; Traidl-Hoffmann, C.; Horres, R.; Pfeifer, M.; Frank, U. Ragweed (Ambrosia artemisiifolia) pollen allergenicity: SuperSAGE transcriptomic analysis upon elevated $\mathrm{CO}_{2}$ and drought stress. BMC Plant Biol. 2014, 14, 1-16. [CrossRef]

52. Wang, H.; Race, E.J.; Shrikhande, A.J. Characterization of anthocyanins in grape juices by ion trap liquid chromatography- mass spectrometry. J. Agric. Food Chem. 2003, 51, 1839-1844. [CrossRef]

53. Ghasemzadeh, A.; Jaafar, H.Z.E.; Karimi, E.; Ibrahim, M.H. Combined effect of $\mathrm{CO}_{2}$ enrichment and foliar application of salicylic acid on the production and antioxidant activities of anthocyanin, flavonoids and isoflavonoids from ginger. BMC Complement. Altern. Med. 2012, 12, 1-10. [CrossRef]

54. Ma, D.; Sun, D.; Wang, C.; Li, Y.; Guo, T. Expression of flavonoid biosynthesis genes and accumulation of flavonoid in wheat leaves in response to drought stress. Plant Physiol. Biochem. 2014, 80, 60-66. [CrossRef]

55. Al-Gabbiesh, A.; Kleinwächter, M.; Selmar, D. Influencing the contents of secondary metabolites in spice and medicinal plants by deliberately applying drought stress during their cultivation. Jordan J. Biol. Sci. 2015, 147, 1-10. [CrossRef]

56. Taub, D.R.; Wang, X. Why are nitrogen concentrations in plant tissues lower under elevated $\mathrm{CO}_{2}$ ? A critical examination of the hypotheses. J. Integr. Plant Biol. 2008, 50, 1365-1374. [CrossRef] [PubMed]

57. Ben-Jabeur, M.; Vicente, R.; López-Cristoffanini, C.; Alesami, N.; Djébali, N.; Gracia-Romero, A.; Serret, M.D.; López-Carbonell, M.; Araus, J.L.; Hamada, W. A novel aspect of essential oils: Coating seeds with thyme essential oil induces drought resistance in wheat. Plants 2019, 8, 371. [CrossRef] [PubMed] 